\title{
Pengaruh Faktor Stres Kerja Terhadap Produktivitas Kerja Karyawan Pada PT. Aido Mini Plaza Sibolga
}

\author{
Misran Tanjung \\ STIE Al-Washliyah Sibolga \\ Harris Hutagalung \\ STIE Al-Washliyah Sibolga
}

\begin{abstract}
Stres sendiri dapat diartikan sebagai suatu kondisi ketegangan yang mempengaruhi emosi, proses pikiran dan kondisi fisik seseorang. Penelitian ini berpusat padapengaruh faktor stres kerja terhadap produktivitas kerja karyawan pada PT. Aido Mini Plaza Sibolga. Populasi dalam penelitian ini sebanyak 114 orang. Pada penarikan sampel dengan cara Disproportionate Stratified Random Sampling diperoleh jumlah sampel 53 orang. Teknik analisis data yang digunakan dengan pendekatan kualitatitif dan kuantitatif. Berdasarkan hasil perhitungan koefisien korelasi pearson product moment diperoleh 0,788 , artinya hubungan faktor stres kerja terhadap produktivitas kerja tergolong hubungan/korelasi kuat.Koefisien determinasi diperoleh $62,1 \%$, hal ini menunjukkan bahwa produktivitas kerja dapat dipengaruhi olehfaktor stres kerja sebesar 62,1\%.Dari uji hipotesis dalam penelitian diperoleh nilai $t_{\text {hitung }}$ lebih besar dari nilai $t$ tabel $(9,162>2,007)$, berarti hipotesis alternatif $\left(\mathrm{H}_{\mathrm{a}}\right)$ diterima, Hasil perhitungan regresi linear sederhana diperoleh persamaan $\mathrm{Y}=13,41+0,76 \mathrm{X}$ artinya yang menunjukkan kearah positif. Berdasarkan hasil uji $\mathrm{F}_{\text {Hitung }}$ diperoleh 83,622 sedangkan $\mathrm{F}_{\text {tabe }}$ sebesar4,03 dari hasil ini diketahui $\mathrm{F}_{\text {hitung }}>\mathrm{F}_{\text {tabel, }}$ dan signifikansi 0,000 atau $\leq \alpha=0,05$ sehingga dapat disimpulkan $\mathrm{H}_{\mathrm{o}}$ ditolak dan $\mathrm{H}_{\mathrm{a}}$ diterima. Untuk memperkecil stres kerja pada aktivitas di PT. Aido Mini Plaza Sibolga dengan cara meningkatkan hubungan yang harmonis antara atasan dan karyawan menjalin kerjasama yang baik antar rekan kerja dan memberi tugas yang sesuai dengan kemampuan karyawan.
\end{abstract}

Keyword Manajemen Keuangan, Kualitas Kinerja, Koefiesien Korelasi

\section{PENDAHULUAN}

\section{A. Latar Belakang}

Sumber daya manusia merupakan kunci pokok yang harus diperhatikan dengan segala kebutuhannya dalam sebuah perusahaan. Sumber daya manusia adalah ujung 
tombak yang akan menentukan keberhasilan pelaksanaan kegiatan perusahaan dan juga merupakan faktor krisis yang dapat menentukan maju mundur serta hidup matinya suatu perusahaan. Dalam dunia bisnis yang berkembang semakin pesat yang terlihat dari persaingan, serta perkembangan pengetahuan dan teknologi yang semakin canggih membawa perubahan pola kehidupan karyawan. Perubahan tersebut mengakibatkan tuntutan yang lebih tinggi terhadap setiap karyawan untuk lebih meningkatkan produktivitas kerjanya, dimana karyawan dituntut dapat memberikan kontribusi kepada lingkungannya, dia imajinatif, dan inovatif, bertanggung jawab dan responsif dalam berkomunikasi dengan orang lain. Produktifitas yang tinggi penting buat perusahaan, karena produktifitas yang tinggi erat kaitannya dengan sumber daya manusia sebagai elemen input yang paling penting.

Stres sendiri dapat diartikan sebagai suatu kondisi ketegangan yang mempengaruhi emosi, proses pikiran dan kondisi fisik seseorang. Stres dapat bersifat sementara atau jangka panjang, ringan atau berat, sangat tergantung pada seberapa penyebabnya berlangsung. Stres yang terlalu besar dapat mengancam kemampuan seseorang untuk menghadapi lingkungan kerjanya. Sebagai hasilnya, pada diri karyawan berkembang berbagai macam gejala stres yang dapat mengganggu pelaksanaan kerjanya. Karyawan yang mengalami stres pada tingkat tertentu dalam suatu organisasi, maka produktivitasnya akan semakin menurun diikuti dengan penurunan kinerja perusahaan. Stres kerja juga dapat menurunkan pemasukan dan keuntungan perusahaan. Kerugian finansial ini disebabkan adanya ketidakseimbangan antara produktivitas dengan biaya yang dikeluarkan untuk membayar gaji, tunjangan, dan fasilitas lainnya. Stres merupakan kondisi dinamik yang di dalamnya seorang individu dihadapkan dengan suatu peluang (opportunity), kendala (constraints), atau tuntutan (demands) yang dikaitkan dengan apa yang sangat diinginkannya dan yang hasilnya dipersepsikan sebagai tidak pasti dan penting.

Segala bentuk stres kerja pada dasarnya disebabkan ketidakmengertian karyawan akan keterbatasannya akan menimbulkan frustasi, konflik, gelisah dan rasa bersalah yang merupakan tipe dasar stres. Setiap kondisi pekerjaan dapat menyebabkan stres, tergantung reaksi karyawan bagaimana menghadapinya. Stres dapat membantu atau merusak produktivitas kerjanya, tergantung seberapa besar tingkat stres yang dialaminya. Jika tidak ada stres, tantangan kerja juga tidak ada dan produktivitas kerja cenderung menurun, sejalan dengan meningkatnya stres, produktivitas kerja cenderung naik karena stres kerja membantu karyawan untuk mengarahkan segala sumber daya dalam memenuhi kebutuhan kerja. Apabila stres kerja terlalu besar, maka produktivitas kerja cenderung menurun karena stres mengganggu pelaksanaan pekerjaan. Karyawan kehilangan kemampuan untuk mengendalikannya, menjadi tidak mampu mengambil keputusan, dan perilakunya menjadi tidak menentu.

PT. Aido Mini Plaza Sibolga merupakan perusahaan ritel yang menjual berbagai macam produk kebutuhan sandang dan pangan. Karyawan PT. Aido Mini Plaza Sibolga dalam menjalankan pekerjaannya dapat mengalami tekanan atau stres, hal ini disebabkan karena menghadapi tanggapan berbagai macam banyak keluhan (complain), permintaan dan informasi yang berhubungan dengan produk yang dijual, sehingga membuat karyawan terutama pramuniaga dan kasir mengalami stres yang ditandai dengan letih, mudah naik pitam, lekas marah. Selain itu faktor jam kerja dan pembuatan shift juga 
mempengaruhi stres kerja karyawan. Kondisi ini juga terjadi pada kasir, jika salah hitung akan mengganti kekurangan selisih dari transaksi yang dilakukannya.

Pada umumnya stres kerja tidak selama bedampak negatif tetapi memiliki nilai positif, dimana jika karyawan dapat mengendalikan stres akibat kerja, kemungkinan akan menjabat posisi jabatan yang lebih tinggi, hal ini diperoleh jika karyawan bekerja pada posisi jabatan supervisor atau Manager Store, Manager Dept. Store, Manager Gamezone, Manager Inventory, Manajer Keuangan, Manager HRD, Manager MD/Purchasing yang memiliki tingkat stres tinggi mengundurkan diri. Karyawan yang dapat mengendalikan stres kerja kemungkinan besar pencapaian produktivitas akan meningkat dan akan menjadi penilaian dari pimpinan perusahaan untuk dipromosikan pada posisi jabatan yang lebih tinggi seperti jabatan supervesor atau manager bagian.

Berdasarkan uraian di atas, maka penulis berminat untuk melakukan penelitian dengan judul : Pengaruh Faktor Stres Kerja Terhadap Produktivitas Kerja Karyawan Pada PT. Aido Mini Plaza Sibolga.

\section{TINJAUAN PUSTAKA}

A. Pengertian Stress Kerja

Stres kerja merupakan kondisi ketegangan yang berpengaruh terhadap emosi, jalan pikiran, dan kondisi fisik seseorang. Stres yang tidak diatasi dengan baik biasanya berakibat pada ketidakmampuan seseorang untuk berinteraksi secara positif dengan lingkungannya, baik dalam arti lingkungan pekerjaan maupun lingkungan luar lainnya. Hal ini karyawan yang bersangkutan akan menghadapi berbagai gejala negatif yang akhirnya akan berpengaruh terhadap produktivitas kerja karyawan. (Siagian Sondang, $2010: 300$ )

Sedangkan menurut Robbins, (2008 : 376) stres kerja menunjukkan "Suatu kondisi dinamika yang di dalamnya seorang individu dikonfrontasikan dengan suatu peluang, kendala, atau tuntutan yang dikaitkan dengan apa yang diinginkan dan yang hasilnya dipersepsikan sebagai tidak pasti dan penting."

\section{B. Pengertian Produktivitas Kerja.}

Menurut Malthis dan Jackson, (2009 : 275) menyatakan produktifitas merupakan "Kemampuan rancangan pekerjaan dalam mencapai target organisasi yang telah ditetapkan."

Kemudian menurut Veithzal, (2010 : 156)menyatakan bahwa : "Produktifitas tidak hanya mencakup aspek-aspek ekonomi, tetapi juga berkaitan dengan aspek non ekonomi, misalnya manajemen dan organisasi, masalah mutu kerja, motivasi, inisiatif dan lain sebagainya"

Kemudian Sinungan, (2008 : 189) menyatakan bahwa produktivitas adalah "Suatu konsep yang universal yang bertujuan menyediakan lebih banyak barang dan jasa untuk lebih banyak manusia, dengan menggunkan sumber-sumber riil yang makin sedikit." 


\section{Pengaruh Faktor Stres Kerja Terhadap Produktivitas Kerja}

Stres kerja dan produktivitasi kerja merupakan 2 (dua) hal yang berbeda, meskipun memiliki tautan dalam konteks kerja. Stres kerja adalah suatu kondisi ketegangan yang menciptakan ketidakseimbangan fisik dan psikis, yang mempengaruhi emosi, proses berpikir, dan kondisi seorang karyawan. Stres dapat membantu atau merusak produktivitas kerja, tergantung seberapa besar tingkat stres itu. Stres tidak ada, tantangan kerja juga tidak ada, dan produktivitasi kerja cenderung menurun, sebaliknya sejalan dengan meningkatnya stres, produktivitas kerja cenderung naik, karena stres membantu karyawan untuk mengarahkan segala sumber daya dalam memenuhi kebutuhan kerja. Stres merupakan suatu rangsangan yang sehat untuk mendorong para karyawan untuk menanggapi tantangan pekerjaan. Stres menjadi terlalu besar, produktivitas kerja akan mulai menurun, karena stres mengganggu pelaksanaan pekerjaan, sehingga stres kerja memiliki pengaruh terhadap produktivitas kerja. Karyawan yang mengalami stres pada tingkat tertentu dalam suatu organisasi, maka produktivitasnya akan semakin menurun diikuti dengan penurunan kinerja perusahaan. Stres kerja juga dapat menurunkan pemasukan dan keuntungan perusahaan. Kerugian finansial ini disebabkan adanya ketidakseimbangan antara produktivitas dengan biaya yang dikeluarkan untuk membayar gaji, tunjangan, dan fasilitas lainnya. Stres merupakan kondisi dinamik yang di dalamnya seorang individu dihadapkan dengan suatu peluang (opportunity), kendala (constraints), atau tuntutan (demands) yang dikaitkan dengan apa yang sangat diinginkannya dan yang hasilnya dipersepsikan sebagai tidak pasti dan penting.

\section{Hubungan Faktor Stres Kerja Terhadap Produktivitas Kerja.}

Dari tinjauan pustaka yang telah uraian sebelumnya dapat digambarkan hubungan faktor stres terhadap produktivitas kerja dapat lihat pada gambar - 1 .

Gambar - 1

Hubungan Faktor Stres Kerja Terhadap Produktivitas Kerja Karyawan

\begin{tabular}{|c|c|}
\hline Faktor Stres Kerja & Produktivitas kerja \\
\hline $\begin{array}{l}\text { 1) Fisik } \\
\text { 2) Prilaku } \\
\text { 3) Watak dan kepribadian } \\
\text { 4) Emosional } \\
\text { 5) Intelektual } \\
\text { 6) Interpersonal }\end{array}$ & $\begin{array}{l}\text { 1. Kuantitas kerja. } \\
\text { 2. Kualitas kerja. } \\
\text { 3. Ketepatan waktu. } \\
\text { 4. Lebih dari memenuhi kualifikasi } \\
\text { pekerjaan. } \\
\text { 5. Bermotivasi tinggi. } \\
\text { 6. Mempunyai orientasi pekerjaan } \\
\text { positif. } \\
\text { 7. Kedewasaan } \\
\text { 8. Dapat bergaul denga efektif }\end{array}$ \\
\hline
\end{tabular}

Sumber : Cary Cooper Handoko; (2009 : 68)dan Robin, (2008 : 155) Moekijat (2010 : 222 


\section{METODE PENELITN}

\section{A. Analisis Koefisien Korelasi}

Uji korelasi pada dasarnya merupakan bentuk pendugaan parameter, untuk menafsir hubungan antara parameter-parameter populasi berdasarkan data sampel. Namun demikian, koefisien korelasi hanyalah menjelaskan seberapa kuat atau lemahnya hubungan antara variabel, berdasarkan data sampel yang dianalisis. Untuk mengetahui koefisien korelasi dapat dilihat pada tabelModel Summary ${ }^{(b)}$ kolom R.Dari hasil perhitungan tersebut akan memperlihatkan kemungkinan- kemungkinan sebagai berikut :

a. Koefisien korelasi yang diperoleh sama dengan nol $(\mathrm{r}=0)$ berarti hubungan kedua variabel yang diuji tidak ada.

b. Koefisien korelasi yang diperoleh positif $(\mathrm{r}=+)$ berarti kenaikan nilai variabel yang satu, diikuti nilai variabel yang lain dan kedua variabel memiliki hubungan positif.

c. Koefisien korelasi yang diperoleh negatif $(\mathrm{r}=-)$, berarti kedua variabel negatif dan menunjukkan meningkatnya variabel yang satu diikuti menurunnya variabel yang lain.

Untuk dapat memberikan penafsiran terhadap koefisien korelasi, maka dapat berpedoman pada ketentuan yang tertera tabel 2 .

Tabel - 2

Interprestasi Koefisien Korelasi

\begin{tabular}{|c|c|}
\hline Interprestasi Koefisien & Tingkat Hubungan \\
\hline $0.80-1.000$ & Sangat kuat \\
$0.60-0.799$ & Kuat \\
$0.40-0.599$ & Sedang \\
$0.20-0.399$ & Rendah \\
$0.00-0.199$ & Sangat Rendah \\
\hline
\end{tabular}

Sumber : Sugiyono (2012: 250)

Dengan nilai $r$ yang diperoleh maka dapat diketahui apakah nilai $r$ yang diperoleh berarti atau tidak dan bagaimana tingkat hubungannya melalui tabel korelasi. Tabel korelasi menentukan batas-batas $r$ yang signifikan. Bila $r$ tersebut signifikan, artinya hipotesis kerja atau hipotesis alternatif dapat diterima.

\section{B. Analisis Kofisien Determinasi}

Uji koefisien determinasi $\left(\mathrm{r}^{2}\right)$ digunakan untuk mengukur seberapa jauh kemampuan model dalam menerangkan varisi variabel dependen. Koefisien determinasi yang digunakan adalani nilai Adjusted $R$ Square dapat naik atau turun apabila satu variabel independen ditambahkan ke dalam model. Berbeda dengan nilai $\mathrm{r}^{2}$ yang pasti akan meningkat setiap tambahan satu variabel independen, tidak peduli apakah variabel tersebut berpengaruh secara signifikan terhadap variabel dependen. 


\section{Uji hipotesis $(U j i-t)$}

Uji t digunakan untuk mengetahui pengaruh variabel bebas terhadap variabel terikatnya, apakah pengaruh nyata atau tidak. Sebagaimana dinyatakan Kuncoro (2008 :73) bahwa uji statistik $t$ adalah uji yang menunjukkan seberapa jauh pengaruh satu variabel penjelas secara individual dalammenerangkan variasi variabel terikat.Kriteria pengujian hipotesis secara parsial adalah sebagai berikut:

1) $\mathrm{H} 0: \mathrm{b} 1=0$, artinya tidak terdapat pengaruh yang positif dan signifikan dari variabel $(\mathrm{X})$ terhadap variabel $(\mathrm{Y})$.

2) $\mathrm{Ha}: \mathrm{b} 1 \neq 0$, artinya terdapat pengaruh yang positif dan signifikan dari variabel $(\mathrm{X})$ terhadap variabel $(\mathrm{Y})$.

Dengan taraf siginifikan $(\alpha)$ menunjukkan tingkat probabilitas terjadinya kesalahan $\alpha=$ $5 \%$ untuk menentukan apakah $\mathrm{H}_{\mathrm{o}}$ ditolak atau diterima yaitu dengan membandingkan $\mathrm{t}$ hitung dengan $\mathrm{t}$ tabel, dengan kriteria :

a. $\mathrm{t}_{\text {hitung }} \geq \mathrm{t}_{\text {tabel }}: \mathrm{H}_{\mathrm{o}}$ ditolak $\mathrm{H}_{\mathrm{a}}$ diterima, artinya ada pengaruh yang nyata antara variabel bebas terhadap varibel terikat

b. $\mathrm{t}_{\text {hitung }} \leq \mathrm{t}_{\text {tabel }}: \mathrm{H}_{\mathrm{o}}$ diterima $\mathrm{H}_{\mathrm{a}}$ ditolak, artinya tidak ada pengaruh yang nyata antara variabel bebas terhadap varibel terikat

\section{Analisis regresi linear sederhana}

Analisis regresi linear sederhana digunakan untuk maksud meramalkan bagaimana keadaan variabel dependen atau variabel terikat, bila variabel independen atau variabel bebas dinaik turunkan nilainya. Model persamaan yang digunakan dalam penelitian ini adalah sebagai berikut : $\mathrm{Y}=\mathrm{a}+\mathrm{bX}$. Untuk mengetahui nilai dari koefisien determinan dapat dilihat hasil software SPSS (Statistical Package for Social Science) pada tabelUnstandardized Coefficients.

\section{E. Uji F (Anova)}

Uji $\mathrm{F}$ dilakukan untuk mengetahui apakah semua variabel bebas yang dimasukkan dalam model mempunyai pengaruh terhadap variabel terikat. Pengaruh variabel independen terhadap variabel dependen diuji dengan tingkat kepercayaan (confidence interval) $95 \%$ atau $\alpha=5 \%$. Jika $\mathrm{F}_{\text {hitung }}<\mathrm{F}_{\text {tabel }}$, maka $\mathrm{H}_{\mathrm{o}}$ diterima dan $\mathrm{H}_{\mathrm{a}}$ ditolak, dan jika $\mathrm{F}_{\text {hitung }}>\mathrm{F}_{\text {tabel }}$, maka $\mathrm{H}_{\mathrm{o}}$ ditolak dan $\mathrm{H}_{\mathrm{a}}$ diterima.

\section{HASIL DAN PEMBAHASAN}

Hasil utama penelitian ini menyatakan bahwa ada pengaruh faktor stres kerja terhadap produktivitas kerja karyawan pada PT. Aido Mini Plaza Sibolga. Analisa data dalam penelitian ini menggunakan uji ANOVA yang mengasumsikan bahwa ada pengaruh faktor stres kerja yang dirasa oleh karyawan pada PT. Aido Mini Plaza Sibolga terhadap produktivitas kerja, sehingga Hipotesa nol pada penelitian ini ditolak dan hipotesa alternatif diterima. Hasil penelitian ini sesuai dengan asumsi sebelumnya bahwa, karyawan yang mengalami stres pada tingkat tertentu dalam suatu organisasi, maka produktivitasnya akan semakin menurun.

Stres kerja juga dapat menurunkan pemasukan dan keuntungan perusahaan. Stres kerja tidak selalu berdampak buruk buat individu. Stres kerja disebut dalam konteks negatif, 
memiliki nilai positif terutama pada saat stres kerja tersebut menawarkan suatu perolehan yang memiliki potensi. Segala bentuk stres kerja pada dasarnya disebabkan ketidakmengertian karyawan akan keterbatasannya yang menimbulkan frustasi, konflik, gelisah dan rasa bersalah merupakan tipe dasar stres. Setiap kondisi pekerjaan dapat menyebabkan stres, tergantung reaksi karyawan bagaimana menghadapinya.

Stres dapat membantu atau merusak produktivitas kerjanya, tergantung seberapa besar tingkat stres yang dialaminya. Jika tidak ada stres, tantangan kerja juga tidak ada dan produktivitas kerja cenderung menurun, sejalan dengan meningkatnya stres, produktivitas kerja cenderung naik karena stres kerja membantu karyawan untuk mengarahkan segala sumber daya dalam memenuhi kebutuhan kerja. Apabila stres kerja terlalu besar, maka produktivitas kerja cenderung menurun karena stres mengganggu pelaksanaan pekerjaan, sedangkan model persamaan regresi linear sederhana diperoleh $\mathrm{Y}=13,41+0,76$ dapat dijelaskan konstanta sebesar 13,41 bahwa, jika tidak ada kenaikan nilai dari variabel faktor stres kerja, maka nilai produktivitas kerja adalah 13,41. Koefisien regresi sebesar 0,76 menyatakan setiap penambahan 1 (satu) skor atau nilai faktor stres kerja akan memberikan peningkatan skor produktivitas kerja 0,76 atau setiap peningkatan faktor stres kerja sebesar $100 \%$, maka produktivitas kerja akan meningkat sebesar $76 \%$, hal ini berlaku jika diasumsikan variabel lain dalam penelitian ini konstan atau ceteris paribus.

Ini sesuai dengan pendapat dari Cary Cooper dan Alison Straw, (2009) mengasumsikan gejala stres dapat mempengaruhi produktivitas kerja, karena faktor yang menjadi sumber stres kerja antara lain fisik, prilaku, watak dan kepribadian, emosional, intelektual, interpersonal.

Hasil penelitian diperoleh koefisien korelasi antara faktor stres kerja terhadap produktivitas kerja sebasar 0,788 yang memberi arti bahwa hubungan antara faktor stres kerja terhadap produktivitas kerja adalah kuat hal ini sesuai dengan pendapat Sugiyono (2012 : 250) bahwa : "Interval koefisien antara 0,60-0,799 mempunyai korelasi kuat."

Nilai thitung dari nilai ttabel $(9,162>2,006)$, maka keputusannya adalah menerima Ha dan Ho ditolak. Hal ini berarti hipotesis yang berbunyi pada BAB I yaitu Ada pengaruh faktor stres kerja terhadap produktivitas kerja karyawan pada PT. Aido Mini Plaza Sibolga dapat diterima.

Koefisien determinasi sebesar 0,621 berarti $62,1 \%$ memberi arti bahwa produktivitas kerja dapat dipengaruhi oleh faktor stres kerja. Sedangkan sisanya 37,9\% dapat dipengaruhi oleh faktor-faktor lain yang tidak dibahas dalam penelitian ini seperti faktor struktur organisasi, motivasi, kepemimpinan dan sebagainya.

Berdasarkan hasil uji F Hitung diperoleh 83,622 sedangkan Ftabel sebesar 4,03 dari hasil ini diketahui $\mathrm{F}$ hitung $>\mathrm{F}$ tabel, dan signifikansi 0,000 atau $\leq \alpha=0,05$ dengan demikian posisi titik uji signifikansi berada pada wilayah penolakan Ho sehingga dapat disimpulkan Ho ditolak dan Ha diterima yang artinya Ada pengaruh faktor stres kerja terhadap produktivitas kerja karyawan pada PT. Aido Mini Plaza Sibolga.

\section{KESIMPULAN DAN SARAN}

\section{A. Kesimpulan}

Berdasarkan hasil analisis dan pembahasan data yang dilakukan pada uraian sebelumnya dalam penelitian ini, dapatdiambil kesimpulan sebagai berikut : 
1. Berdasarkan hasil perhitungan koefisien korelasi pearson product moment diperoleh 0,788 , artinya hubungan faktor stres kerja terhadap produktivitas kerja tergolong hubungan/korelasi kuat.

2. Hasil perhitungan koefisien determinasi diperoleh $62,1 \%$, hal ini menunjukkan bahwa produktivitas kerja dapat dipengaruhi olehfaktor stres kerja sebesar $62,1 \%$,sedangkan sisanya sebesar $37,9 \%$ dipengaruhi oleh faktor lain yang tidak dibahas dalam penelitian ini, seperti faktor struktur organisasi, koordinasi dan sebagainya.

3. Dari uji hipotesis dalam penelitian diperoleh nilai $t_{\text {hitung }}$ lebih besar dari nilai $t$ tabel $(9,162>2,007)$, berarti hipotesis alternatif $\left(\mathrm{H}_{\mathrm{a}}\right)$ diterima, jadi hipotesis yang diajukan BAB I dapat diterima.

4. Berdasarkan hasil perhitungan regresi linear sederhana diperoleh persamaan $\mathrm{Y}=$ $13,41+0,76 \mathrm{X}$ artinya yang menunjukkan kearah positif.

5. Berdasarkan hasil uji $\mathrm{F}_{\text {Hitung }}$ diperoleh 83,622 sedangkan $\mathrm{F}_{\text {tabel }}$ sebesar4,03 dari hasil ini diketahui $\mathrm{F}_{\text {hitung }}>\mathrm{F}_{\text {tabel, }}$ dan signifikansi 0,000 atau $\leq \alpha=0,05$ dengan demikian posisi titik uji signifikansi berada pada wilayah penolakan $H_{o}$ sehingga dapat disimpulkan $\mathrm{H}_{\mathrm{o}}$ ditolak dan $\mathrm{H}_{\mathrm{a}}$ diterima yang artinya Adapengaruh faktor stres kerja terhadap produktivitas kerja karyawan pada PT. Aido Mini Plaza Sibolga.

\section{B. Saran}

Berdasarkan kesimpulan tesebut di atas, maka penulis merasa perlu memberikan saran dan masukan yang berguna untuk instansi yaitu :

1. Untuk memperkecil stres kerja pada aktivitas di PT. Aido Mini Plaza Sibolga dengan cara meningkatkan hubungan yang harmonis antara atasan dan karyawan menjalin kerjasama yang baik antar rekan kerja dan memberi tugas yang sesuai dengan kemampuan karyawan.

2. Agar perusahaan lebih menerapkan sistem manajemen yang baik, sehingga perusahaan dapat beroperasi secara efektif dan efisien.

3. Kepada PT. Aido Mini Plaza Sibolga perlu melakukan managemen stres untuk mengurangi tingkat stres yang dialami seperti self relaksation.

\section{REFERENSI}

Agus. Siswanto, 2005, Manajemen Kinerja, Jakarta: Gramedia Pustaka Utama

Azwar, S. 2012, Reliabilitas dan validitas, Yogyakarta : Pustaka Pelajar

Cary Cooper dan Alison Straw, 2009, Fathudin, Stres Manajemen Sukses Dalam Sepekan. Jakarta : Kesaint Blanc

Davis, Keith dan Newstrom Shon W, 2009. Perilaku Dalam Organisasi. Edisi Ketujuh Belas. Jakarta: Erlangga 
Ghozali, Imam, 2005, Aplikasi Analisis Multivariate dengan Program SPPS,Edisi Ketiga, Semarang : Badan Penerbit Universitas Diponegoro

Gitosudormo, Indriyo dan Nyoman Sudita, 2009, Perilaku Keorganisasian. Cetakan Pertama. Yogyakarta : PT. BPFE

Hadi, S. 2010, Metodology Research, Jilid Ketiga, Yogyakarta : Andi Offset

Handoko. T. Hani, 2009, Manajemen Sumber Daya Manusia, Cetakan Kesepuluh, Jakarta: Bumi Aksara

Hasibuan Malayu. S. P, 2010.Manajemen Sumber Daya Manusia, Cetakan Ketujuh, Jakarta: Bumi Aksara

John Supriharto T.H, Agung M, Harsiwi, Prakoso Hadi, 2008,Prilaku Organisasional, Cetakan Kedua, Yogyakarta STIE YKPN

Kuncoro, M, 2008, Metode Riset untuk Bisnis dan Ekonomi: Bagaimana Meneliti dan Menulis Tesis?, Jakarta: Erlangga

Malthis, L. Robert and Jackson, H. John. 2009. Diana Angelica, Human Resource Management (Manajemen Sumber Daya Manusia), Edisi Sebelas, Terjemahan. Jakarta: Salemba Empat

Mangkunegara Anwar Prabu, 2010, Manajemen Sumber Daya Manusia. Bandung : Remaja Rosda Karya,

Moekijat, 2010, Dasar-Dasar Pengetahuan Tentang Manajemen Perkantoran, Edisi Revisi II, Bandung : Mandar Maju

Prasetyo, B., 2009, Metode Penelitian Kuantitatif Teori dan. Aplikasi, Jakarta : Raja Grafindo Persada

Rice, P. L, 2010, Stress and Health : Principle and Practice for Coping and Wellness. California :Wadsworth, Inc.

Riduwan, 2008,BELAJAR MUDAH PENELITIAN, Untuk Guru - Pegawai Dan Peneliti Pemula, Cetakan Keenam, Bandung : Alpa Beta

Robbins. Stephen P, 2008, Perilaku Organisasi, Jilid Kedua, Jakarta : Indeks

Sasono. Eko, 2012, Mengelola Stress Kerja. Semarang : Universitas Pandanaran

Sedarmayanti. 2009, Restrukturisasi dan Pemberdayaan Organisasi Untuk Menghadapi Dinamika Perubahan Lingkungan. Bandung: Mandar Maju 
Siagian, Sondang. P, 2010, Manajemen Sumber Daya Manusia. Cetakan Kesebelas. Jakarta:Rineka Cipta

Sinungan, Muchdarsyah, 2008, Produktivitas Apa dan Bagaimana, Jakarta: Bumi Aksara

STIE Al-Washliyah Sibolga/Tapanuli Tengah, 2015, Pedoman Penulisan dan Penyusunan Skripsi, Sibolga

Sugiyono, 2012, Metode Penelitian Bisnis. Bandung: Alfa Beta

TampubolonIrma. S. M, 2009,Pengaruh Stress Kerja Terhadap Prestasi Kerja Karyawan Pada PT. Pabrik Es Pematangsiantar. Skripsi. Pematangsiantar.

Veithzal. Rivai, 2010. Manajemen Sumber Daya Manusia untuk Perusahaan. Jakarta: Grapindo Persada

Wijono, S, 2010,Psikologi Industri Dan Organisasi, Dalam Suatu Bidang Gerak Psikologi Sumber Daya Manusia, Edisi 1. Jakarta : Kencana. 